\title{
Effect of Street Morphology on Buildings' Thermal Storage in a Hot and Arid Climate: Case Study of Biskra (Algeria)
}

\author{
Benamor $\mathrm{K}^{*}$, Benabbas M
}

\begin{abstract}
Laboratory LACOMOFA, Department of Architecture, University Mohamed Khider Biskra, Algeria. Corresponding Author: kaouther61@gmail.com
\end{abstract}

Received: 25-05-2019

Accepted: 12-09-2019

\begin{abstract}
This work is an experimental study focusing on the relationship between street morphology and thermal storage in buildings. The first aim of this study is to reduce air conditioning usage in hot and arid areas, taking as example Biskra city (Algeria), during the long summer period ( 5 months), by reducing thermal storage. This leads to the reduction of carbon emissions to a level higher than the individual construction level in order to design a sustainable city, using measuring instruments (kimo HD 100 and Cason CA 380), we measured outdoor air temperature, wall temperature, relative humidity and wind speed on three street morphologies ; the (canyon, dihedral and open streets). These streets are different in terms of morphological indicators such as Sky View Factor (SVF) and albedo materials (a). We also applied mathematical equations across the thermal balance to calculate thermal storage. Our second goal was to identify the morphological indicators of the streets affecting the thermal storage of buildings. In this context, the obtained results showed that SVF was the most influential parameter on the heat storage.
\end{abstract}

Key words: Street morphology, Thermal storage, Sustainable city, Hot and arid climate, Sky View Factor (SVF), Albedo materials (a), Air conditioning.

\section{Introduction}

According to the fourth report of the Intergovernmental experts on climate change (IECC) in 2007 , the temperature of the Earth could rise from $1.1^{\circ} \mathrm{C}$ to $6.4^{\circ} \mathrm{C}$ by the end of the $21^{\text {st }}$ century (Coquillaud, 2015). Furthermore, developing countries that have a hot and arid climate are the vulnerable ones to climate change. Algeria is among the affected African countries because of the region's diverse climate with a Mediterranean climate in the north and an arid climate in the south.

This case study is conducted on the town of Biskra which is located in the south-east of Algeria in order to reduce the temperature in the city, also called the Urban Heat Island (UHI) phenomenon and thus, to reduce the active air conditioning and $\mathrm{CO} 2$ emissions, on a superior level than the individual construction (Arantes et al., 2016). In this way, it is better to adopt an energy strategy in the design of efficient cities in the long term, by working on the urban form, through the morphological indicators of the streets (Bouyer, 2009). At this level, there is an interaction between the external environment and the thermal comfort inside the buildings (Nikolopoulou et al., 1999), as the street is a thermal regulator between the inside and the outside and a key factor that influences the heat storage in buildings (Golany, 1996; Adolphe, 2001), therefore, this article studies the effect of street morphology on the thermal storage of buildings in a hot and arid climate, in order to protect the environment and reach a sustainable city.

\section{Presentation of the case study}

The area that represents our case study is located in the East of the called river Sidi Zerzour (76 residential quarters), it is $2 \mathrm{~km}$ far from the city center (Figure 1 ). 

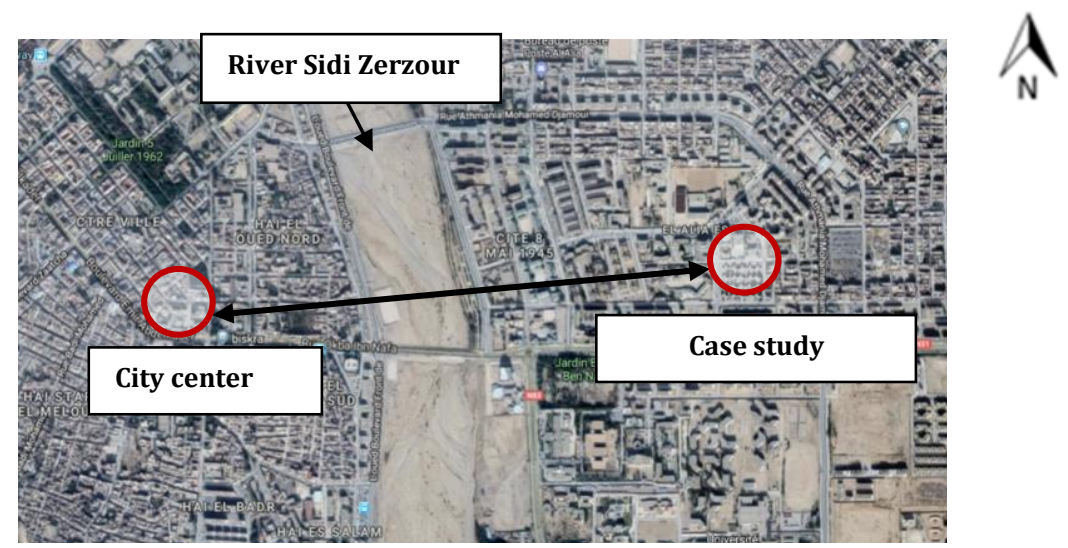

Fig. 1. Location of the 76 residential quarter. Source: Google Earth (2016).

This neighborhood was selected based on the following criteria:

- Urban geometry: morphological diversity.

- The geographical situation: far from the center in order to neglect the impact of anthropogenic flux.

- The absence of vegetation: in order to neglect the latent flux impact.

This site is characterized by a morphological diversity which allowed us to neglect the impact of anthropogenic and latent heat fluxes that enter in the thermal balance calculation. These considerations allowed us to take into account only the criteria related to the morphology of the street and the thermal exchange of the mineral surface.

\subsection{Climate data of Biskra town}

A large part of southern Algeria is a Sahara desert (2 million $\mathrm{Km}^{2}$ ) representing about $85 \%$ of its all surface. The town of Biskra which represents our case study is located in the South-East of the country (Figure 2).
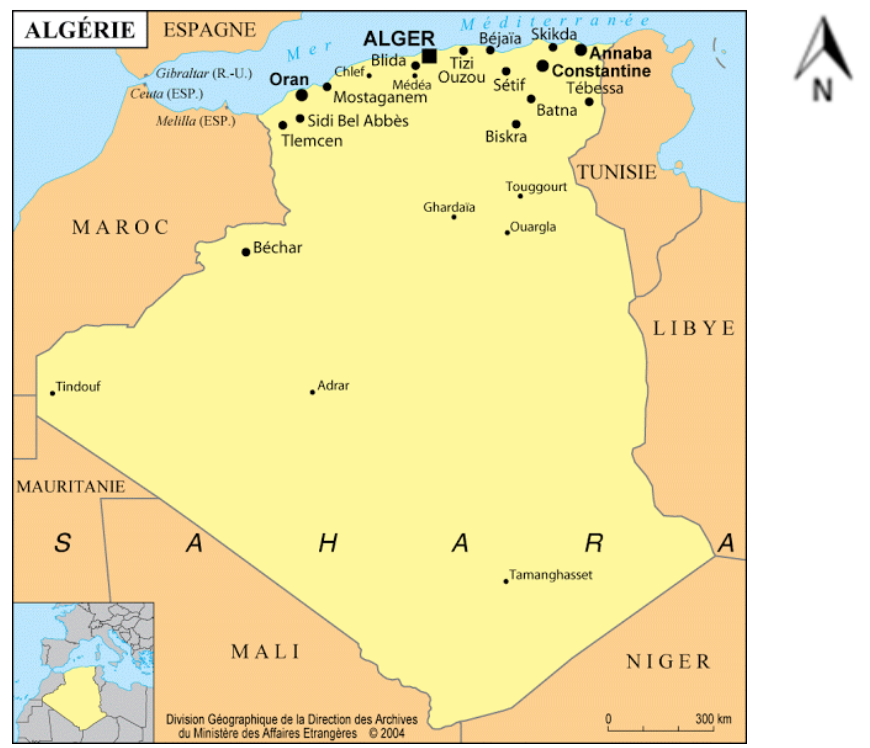

Fig. 2. Location of Biskra city - Source: Wikipedia.

According to Biskra climate data of the ten years (2005-2015) (Table 1), the average of the aridity index of De Martonne ( $\left.\mathrm{I}_{\mathrm{DM}}\right)$, is 5.64 which indicates that this city is located in the arid zone (Table2). 
$\mathrm{I}_{\mathrm{DM}}=\frac{\mathrm{P}}{\mathrm{T}+10}$

Where:

$\mathrm{I}_{\mathrm{DM}}$ : De Martonne aridity index.

P: Annual total precipitation.

$\mathrm{T}$ : annual mean temperature.

The De Martonne aridity index climate classification is given as follows:

Table 1. Averages of annual precipitation and air temperature during 2005-2015 (Biskra weather station, 2017).

\begin{tabular}{|c|c|c|c|c|c|c|c|c|c|c|c|}
\hline Years & 2005 & 2006 & 2007 & 2008 & 2009 & 2010 & 2011 & 2012 & 2013 & 2014 & 2015 \\
\hline $\begin{array}{c}\text { Average P } \\
(\mathrm{mm})\end{array}$ & 14.74 & 10.94 & 16.38 & 14.73 & 10.17 & 7.68 & 1.10 & 2.05 & 22.27 & 29.85 & 14.47 \\
\hline $\begin{array}{c}\text { Average T } \\
\left({ }^{\circ} \mathrm{C}\right)\end{array}$ & 12.25 & 14.39 & 16.81 & 22.19 & 27.27 & 31.24 & 35.56 & 34.41 & 30.44 & 24.39 & 17.77 \\
\hline $\mathrm{T}+10$ & 22.25 & 24.39 & 26.81 & 32.19 & 37.27 & 41.24 & 45.56 & 44.41 & 40.44 & 34.39 & 27.77 \\
\hline $\begin{array}{c}\text { IDM } \\
=\mathrm{P} / \mathrm{T}+10\end{array}$ & 0.66 & 0.45 & 0.61 & 0.46 & 0.27 & 0.18 & 0.024 & 0.046 & 0.55 & 0.87 & 0.52 \\
\hline
\end{tabular}

P: Precipitation, T: Temperature.

Table 2. De Martonne aridity index climate classification (Guyot, 1999).

\begin{tabular}{|c|c|}
\hline $\mathrm{I}_{\mathrm{DM}}$ Value & Climatic conditions \\
\hline $\mathrm{I}_{\mathrm{DM}}<5$ & Hyper-Arid \\
\hline $5<\mathrm{I}_{\mathrm{DM}}<10$ & Arid \\
\hline $10<\mathrm{I}_{\mathrm{DM}}<20$ & Semi-Arid \\
\hline $\mathrm{I}_{\mathrm{DM}}>20$ & Humid \\
\hline
\end{tabular}

The climate of this region is characterized by two seasons, a very hot and dry climate in summer and a cold relatively wet winter, with a short period of comfort. The maximum temperature reaches $46.5{ }^{\circ} \mathrm{C}$ in July (summer) and the minimum temperature decreases to $1.67{ }^{\circ} \mathrm{C}$ during January (winter). The average annual temperature is about $23.31^{\circ} \mathrm{C}$, while the annual average humidity is $45.60 \%$. A very low rainfall with a maximum of $29.85 \mathrm{~mm} /$ year and an annual average of about $11.3 \mathrm{~mm} /$ year are recorded. The predominant winds are North-West in winter, at a speed of $40 \mathrm{~km} / \mathrm{h}$, average, and South-East in the summer at a speed of around $20 \mathrm{~km} / \mathrm{h}$. In spring and autumn, the winds are hot and dusty, blowing from South-West to South-East, reaching $80 \mathrm{~km} / \mathrm{h}$. (Fig. 3 and 4).
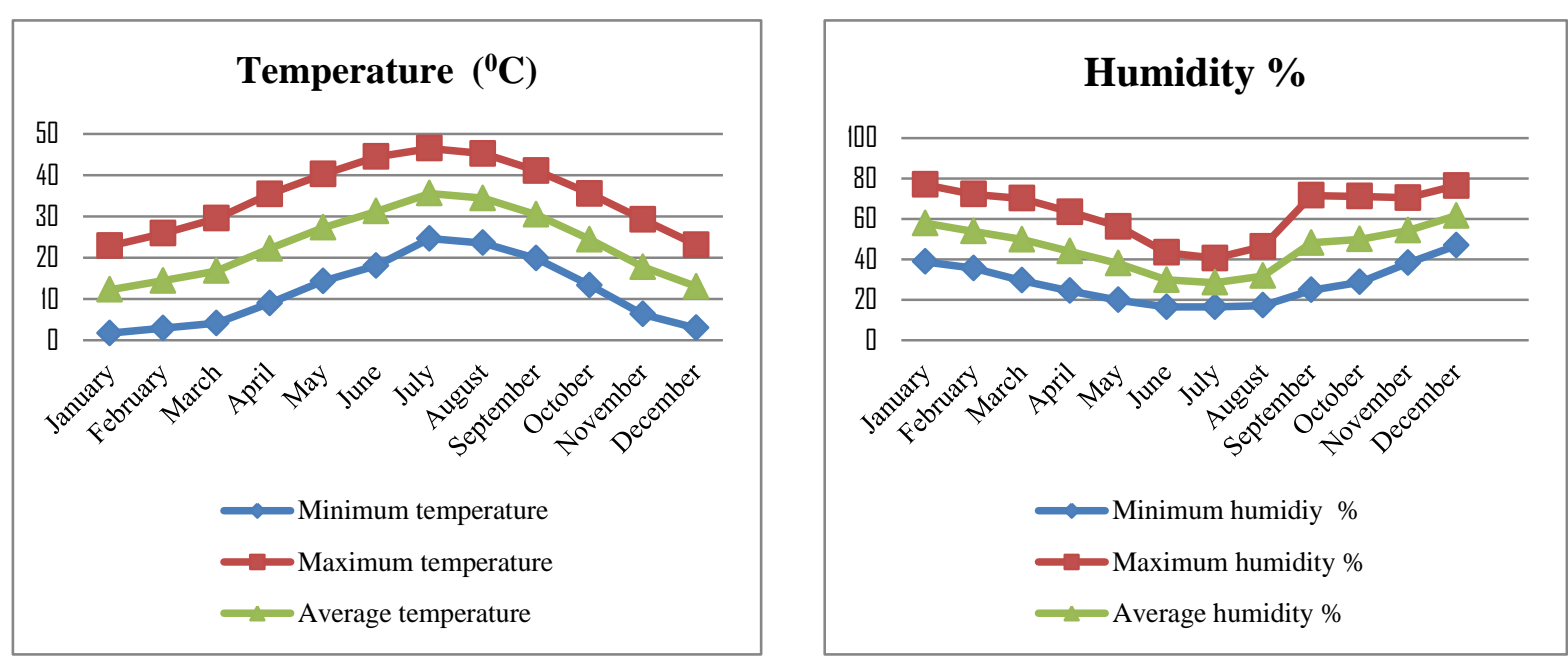

Fig. 3. The temperature and humidity data of Biskra city (Biskra weather station, 2005-2015). 

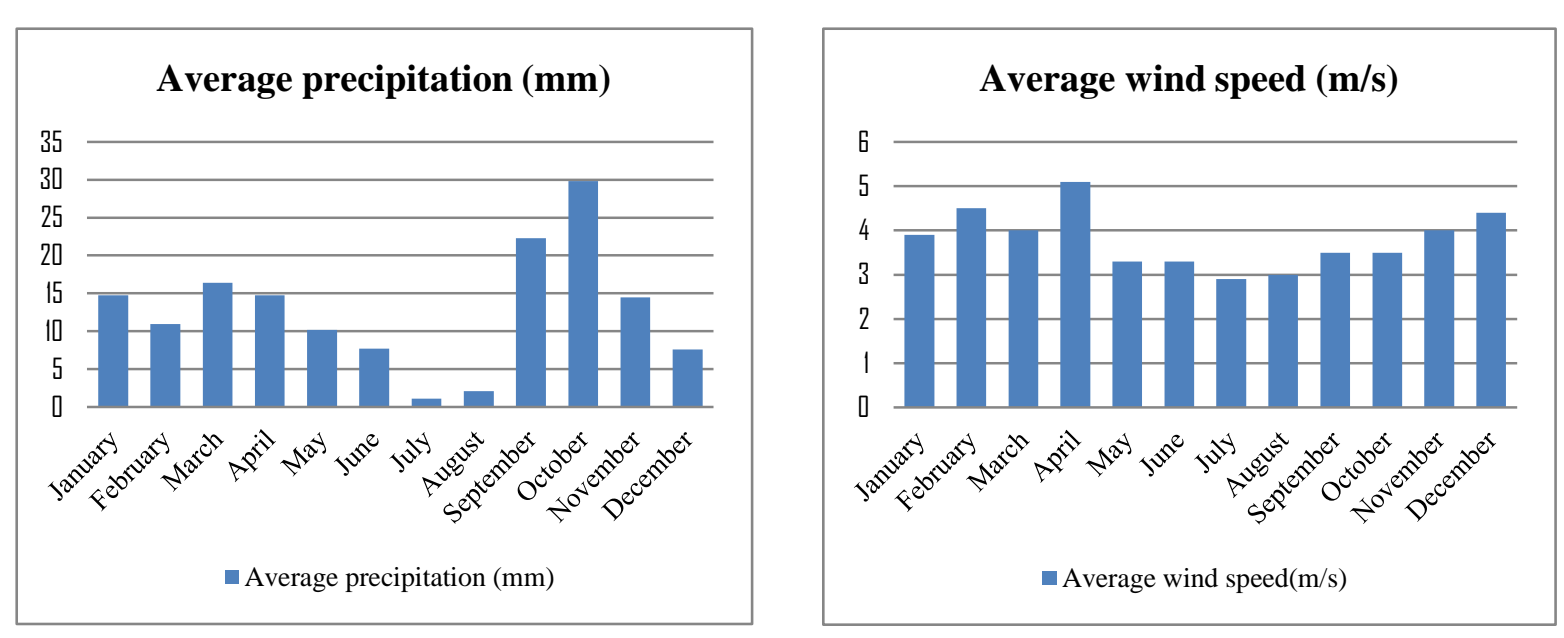

Fig. 4. Average monthly precipitation and wind speed of Biskra city (Biskra weather station, 2005-2015).

\section{Methodology}

The adopted method was based on four measurements (wall temperature- outdoor air temperature- wind speed and relative humidity). These measurements were collected at three types of streets (the Canyon, the Dihedral and the Open streets) different in terms of the two morphological indicators: 1- Sky View Factor (SVF) and 2- albedo materials (a). These measurements were collected using the measuring instruments (kimo HD 100 and Cason CA 380) (Table 3).

Table 3. The measuring instruments.

\begin{tabular}{|c|c|}
\hline Instruments & Characteristics \\
\hline $\begin{array}{l}\text { 1- Electronic thermo- } \\
\text { hygrometer HD } 100\end{array}$ & $\begin{array}{l}\text { is used to measure three climatic } \\
\text { parameters, that of the air temperature in }\left(^{\circ}\right. \\
\left.\mathrm{C},{ }^{\circ} \mathrm{F}, \mathrm{K}\right) \text {, the relative humidity }(\%) \text {, and the } \\
\text { dew point }\left({ }^{\circ} \mathrm{C},{ }^{\circ} \mathrm{F}, \mathrm{K}\right) \text { on beaches } \\
\text { measurements ranging from }-20^{\circ} \mathrm{C} \text { to }+80^{\circ} \\
\mathrm{C} \text { for air temperature and dew point, and } 5 \\
\text { to } 95 \% \text { for } \mathrm{RH} \text {. While the resolution is }(0.1 \% \\
\left.\mathrm{RH}, 0.1^{\circ} \mathrm{C}\right) \text {. }\end{array}$ \\
\hline 2- LV 100 Anemometer & $\begin{array}{l}\text { The instrument is used to record the flow of } \\
\text { air in circulation, the measuring ranges are } \\
\text { limited to: } 0.2 \mathrm{~m} / \mathrm{s} \text { to } 3.1 \mathrm{~m} / \mathrm{s}-3.1 \mathrm{~m} / \mathrm{s} \text { to } \\
35 \mathrm{~m} / \mathrm{s} \text {. the resolution of the anemometer } \\
\text { shows a difference of } 0.01 \mathrm{~m} / \mathrm{s} \text { to } 0.1 \mathrm{~m} / \mathrm{s} \text {. }\end{array}$ \\
\hline Source : www.Kimo.fr & \\
\hline $\begin{array}{l}\text { 3- The Cason } \\
\text { thermometer CA } 380\end{array}$ & $\begin{array}{l}\text { Measures the surface temperature of the } \\
\text { materials composing the built mass by } \\
\text { means of an infrared ray. }\end{array}$ \\
\hline
\end{tabular}

Measurements were taken during critical hours, in the afternoon $(16.00 \mathrm{~h}$ where the facades are very exposed to solar radiations) and before sunrise $(04.00 \mathrm{~h})$, during a typical summer day 
(July $17^{\text {th }}$ 2016). This day is the hottest one, where the sky is clear and the wind is very weak, this makes the best local thermal conditions.

Once the microclimatic measurements are complete, we calculated the thermal storage, which was done through the thermal balance.

\subsection{Placement of measuring stations}

To locate our stations, we chose the East-West axis because of significant access to solar radiation in the West facades (Figure 5 and 6).

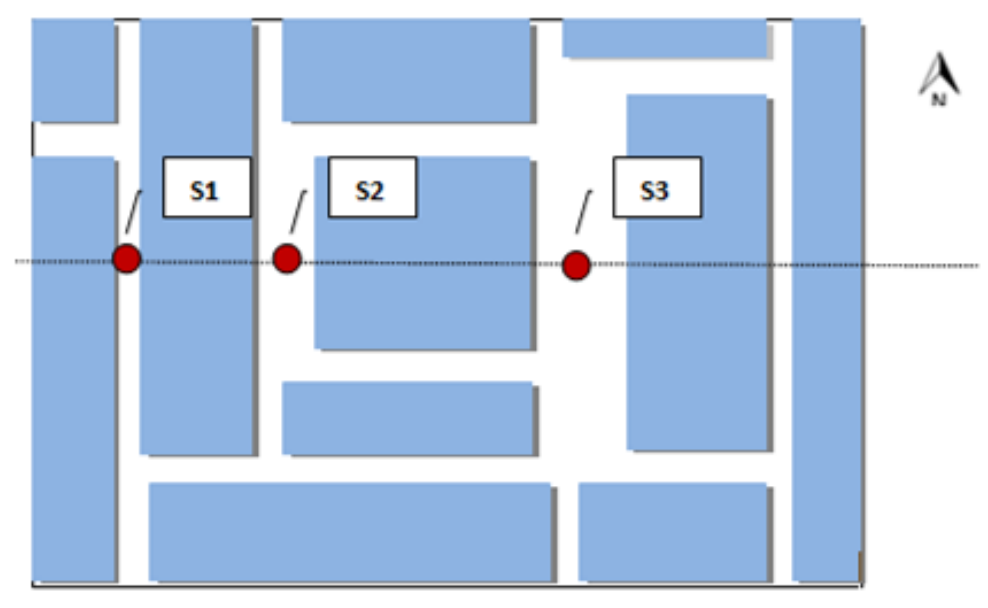

Fig. 5. The measurement points in the streets (scale: 1/1000).

(a)

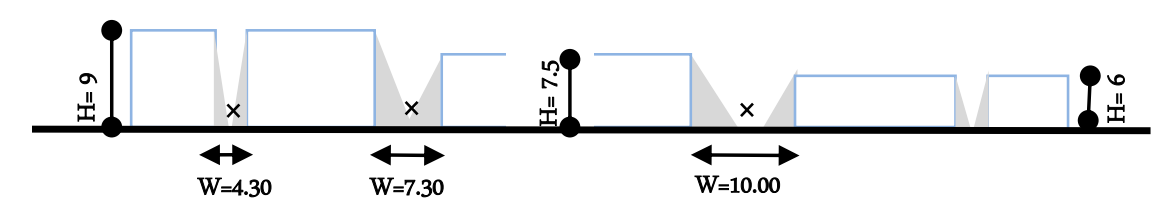

S1

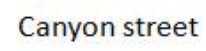

$(\mathrm{H} \geq 2 \mathrm{~W})$

(b)

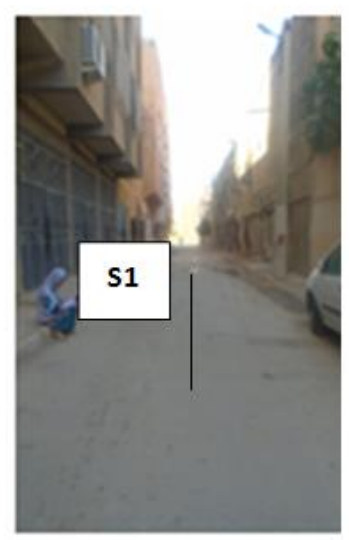

S2

Dihedral street $(\mathrm{H}=\mathrm{W}$, or $\mathrm{H}=0.5 \mathrm{~W})$

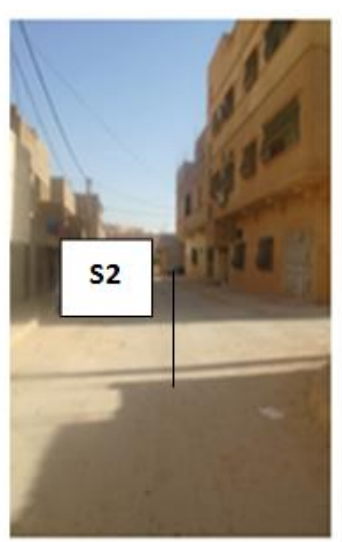

S3

Open Street

$(\mathrm{H} \geq 0.25 \mathrm{~W})$

Fig. 6. a) Urban section, scale: $1 / 1000$.b) Stations' situation.

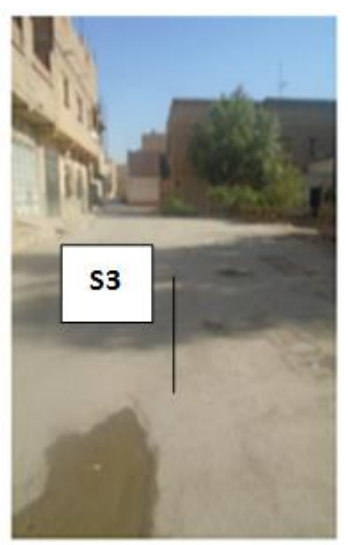


The three streets in particular differ in terms of: the opening to the sky, exposure to solar radiation, and the nature of materials and the height of adjacent buildings ...etc The morphological indicators calculations of this study are based on the mathematical process, as shown in the equations below, this seems to be appropriate for determining the thermal exchanges in the street. All these indicators are summarized in (table 4).

- $\quad$ Sky view factor (SVF)

The SVF was calculated according to the equation of Oke and Cleugh (1987).

$\Psi_{\text {sky }}=\left(1-2 \Psi_{\text {wall }}\right)$

$\Psi_{\text {wall }}=0.5\left(\sin ^{2} \theta+\cos \theta-1\right)(\cos \theta)^{-1}$

$\boldsymbol{\theta}=\tan ^{-1}(\mathrm{H} / 0.5 \mathrm{~W})$

\section{- Materials' albedo (a)}

The albedo of materials was calculated according to a visual analysis of the percentage of occupation of each material in the facade (Ahmed Ouameur, 2007).

Table 4. Morphological features of three streets. (Benamor, 2017).

\begin{tabular}{|l|l|l|l|}
\hline \multirow{2}{*}{ Streets } & \multicolumn{3}{|l|}{ Morphological indicators } \\
\cline { 2 - 4 } & $\begin{array}{l}\text { Sky View Factor } \\
\text { (SVF) }\end{array}$ & $\begin{array}{l}\text { Percentage occupancy of the } \\
\text { albedo on the West façade } \%\end{array}$ & $\begin{array}{l}\text { Albedo material } \\
\text { (a) }\end{array}$ \\
\hline Canyon & 0.25 & Red bricks: 30 & 0.35 \\
street & & Concrete bricks wall : 65 & 0.25 \\
(S1) & & Ceramic : 5 & 0.30 \\
\cline { 3 - 4 } & & & $0.28 \approx 0.30$ \\
\hline Dihedral & 0.45 & Red bricks: 30 & 0.35 \\
street & & Concrete bricks wall: 60 & 0.25 \\
(S2) & & wall coating: 10 & 0.45 \\
& & & 0.30 \\
\hline Open & 0.65 & Red bricks: 30 & 0.35 \\
street & & Concrete bricks wall: 70 & 0.25 \\
(S3) & & & $0.28 \approx 0.30$ \\
\hline
\end{tabular}

\section{Thermal balance (thermal storage)}

The system (urban environment, neighborhood, green space, infrastructures, buildings, streets, etc.) acts as an environment that can store heat during the day and releases it during the night time (Parmentier, 2010).

According to Masson et al. (2002), the thermal balance can be written according to the following equation:

$Q^{*}+Q_{F}=Q_{H}+Q_{E}+\Delta Q_{S}\left(W / m^{2}\right)$

$Q^{*}$ : Net radiation $\left(\mathrm{W} / \mathrm{m}^{2}\right)$

QF: Anthropogenic heat flux $\left(\mathrm{W} / \mathrm{m}^{2}\right)$

$\mathbf{Q}_{\mathrm{H}}$ : Sensible heat flux $\left(\mathrm{W} / \mathrm{m}^{2}\right)$

$\mathbf{Q}_{\mathrm{E}}$ : Latent heat flux $\left(\mathrm{W} / \mathrm{m}^{2}\right)$

$\mathbf{Q}_{\mathrm{G}}$ : Conductive heat flux $\left(\mathrm{W} / \mathrm{m}^{2}\right)$ 
In our case, we have neglected the impact of anthropogenic heat flux and latent flux since the site is far from the city center and does not have any green space, in this way, our thermal balance will be defined by the equation:

$\mathbf{Q}^{*}=\mathbf{Q}_{\mathbf{H}}+\mathbf{Q}_{\mathbf{G}}$

So the formula for calculating the thermal storage in buildings can be written as follow:

Thermal Storage $=\mathbf{Q}^{*} \cdot \mathbf{Q}_{H}-\mathbf{Q}_{G}$

\subsection{Sensible heat flux $(Q H)$}

The sensible heat flux was calculated using the equation:

$\mathbf{Q}_{\mathrm{H}}=\mathbf{h c}\left(\mathbf{T}_{\text {air }}-\mathbf{T}_{\text {wall }}\right)$

$\mathrm{T}_{\mathrm{a}}=$ Temperature of the outside air $\left({ }^{\circ} \mathrm{C}\right)$

$\mathrm{T}_{\text {wall }}=$ Wall temperature $\left({ }^{\circ} \mathrm{C}\right)$

hc $=0,5+1,2 \sqrt{s_{\text {wind }}}$

hc: Coefficient of thermal convection

$\mathrm{s}_{\text {wind }}=$ Wind speed

\subsection{Conductive heat flux (QG)}

The conductive heat flux was defined by Oke and Cleugh (1987) as it follows:

$\mathrm{G}=-\mathrm{k}\left(\Delta \mathrm{T} / \Delta_{\mathrm{X}}\right) \approx-\mathrm{k}\left(\Delta \mathrm{T} /\left(\frac{\Delta e}{e}\right)\right)$

$\Delta \mathrm{T}=$ Coldest and hottest temperature $(\mathrm{K})$

$\mathrm{e}=$ Level of $\Delta \mathrm{T}(\mathrm{m})$

$\mathrm{K}$ : Thermal conductivity of wall $=0.12 \mathrm{w} / \mathrm{m} / \mathrm{k}$

\subsection{Net radiation $\left(Q^{*}\right)$}

According to Colombert (2008), the urban surfaces were exposed to direct solar radiation from the sun and diffused solar radiation (due to multiple reflections from the sky and the soil). The net radiation can be written according to the equation below:

$\mathbf{Q}^{*}=\mathbf{Q}_{\text {direct solar radiation received on the wall }}+\mathbf{Q}$ diffuse solar radiation (multiple reflections)

Direct solar radiation and diffuse radiation are defined according to Masson et al. (2002), by the following equation:

\subsubsection{Direct solar radiation received on the wall}

$Q_{\text {direct solar radiation received on the wall }}=Q_{\text {Direct (sun) }}\left(\frac{H}{W}\left(\frac{1}{2}-\frac{o_{0}}{\pi}\right)+\frac{1}{\pi} \tan (\varphi)\left[1-\cos \left(O_{0}\right)\right]\right)$

$\mathrm{H}=$ Height of street

W= Width of street

$\varphi=$ Solar altitude 
$O_{0}=$ Solar azimuth angle

$Q_{\text {Direct (sun) }}=A \cdot \exp \frac{-1}{B \cdot \sin (h+C)}$ (Perrin de brichambaut $)$

With $A, B$ and $C$ as the empirical constants that depend on the nature of the sky

With their values as: $\mathrm{A}=1230, \mathrm{~B}=3.8, \mathrm{C}=1.6$ in normal clear sky conditions.

\subsubsection{Diffuse solar radiation}

According to Masson et al. (2002), diffuse solar radiation between walls is expressed by the following:

$Q_{\text {diffuse solar (multiple reflections) }}=\Psi_{\text {wall }} \cdot Q_{\text {diffuse sky }}$

$\Psi_{\text {wall }}=\frac{1}{2} \frac{\frac{H}{W}+1-\sqrt{\left(\frac{H}{W}\right)^{2}+1}}{\frac{H}{W}}$

$Q_{\text {diffuse sky }}=E .(\sin h)^{0.4}($ Perrin de brichambaut $)$

The value of the empirical constant $\mathrm{E}$ is 125 for normal clear sky conditions.

\section{Results and discussion}

The figures 7 show that the value of albedo (a) is fixed at 0.30 in all the measurements of the stations, because of the same construction materials used in the facades (brick and concrete). However, the $\mathrm{QH}, \mathrm{QG}$, and $\mathrm{Q}^{*}$ values are variable

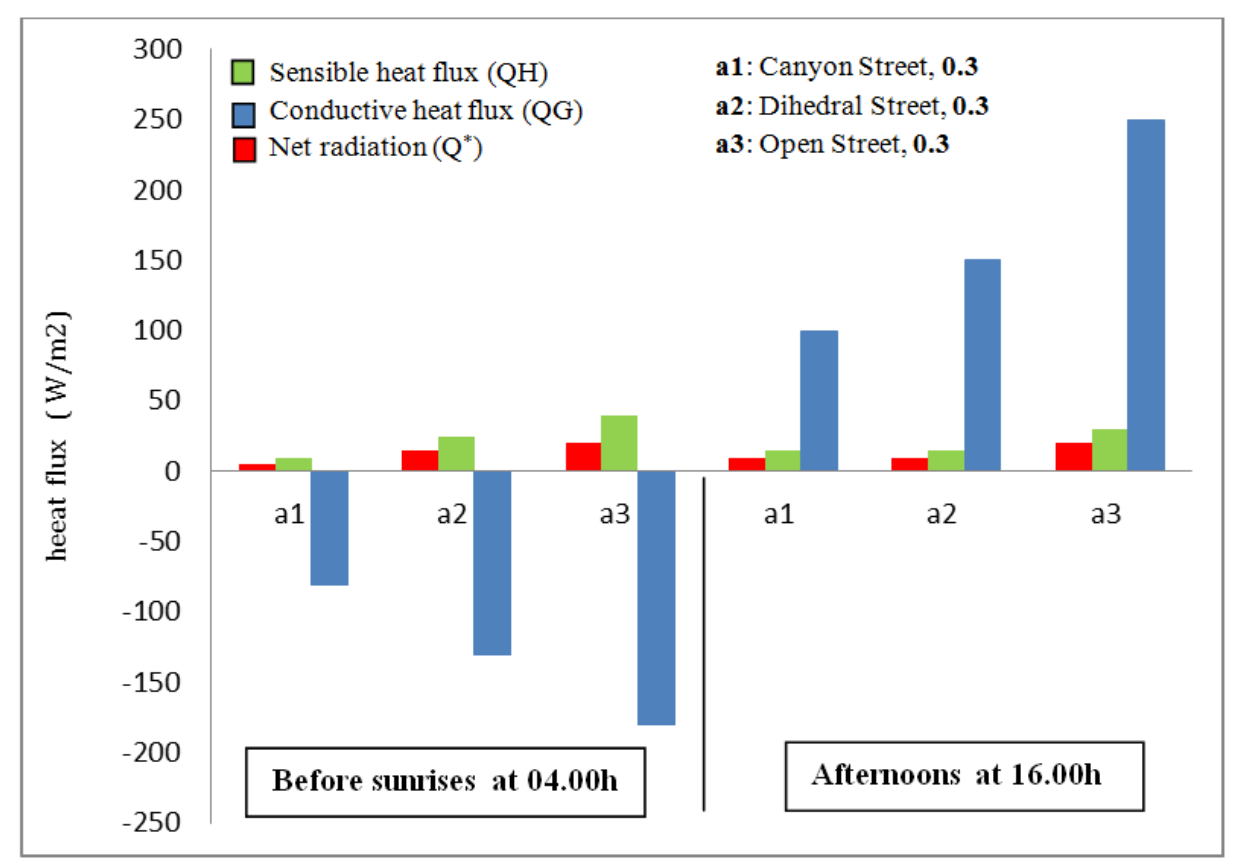

Fig. 7. Relationship between albedo material (a) and sensible heat flux $(\mathrm{QH})$, conductive heat flux (QG) and net radiation $\left(Q^{*}\right)$.

This means that the albedo indicator is not the only cause that can influence the energy balance of the facades and thermal exchange at the street level, but there is also the effect of Sky View Factor (SVF) (fig 8). 


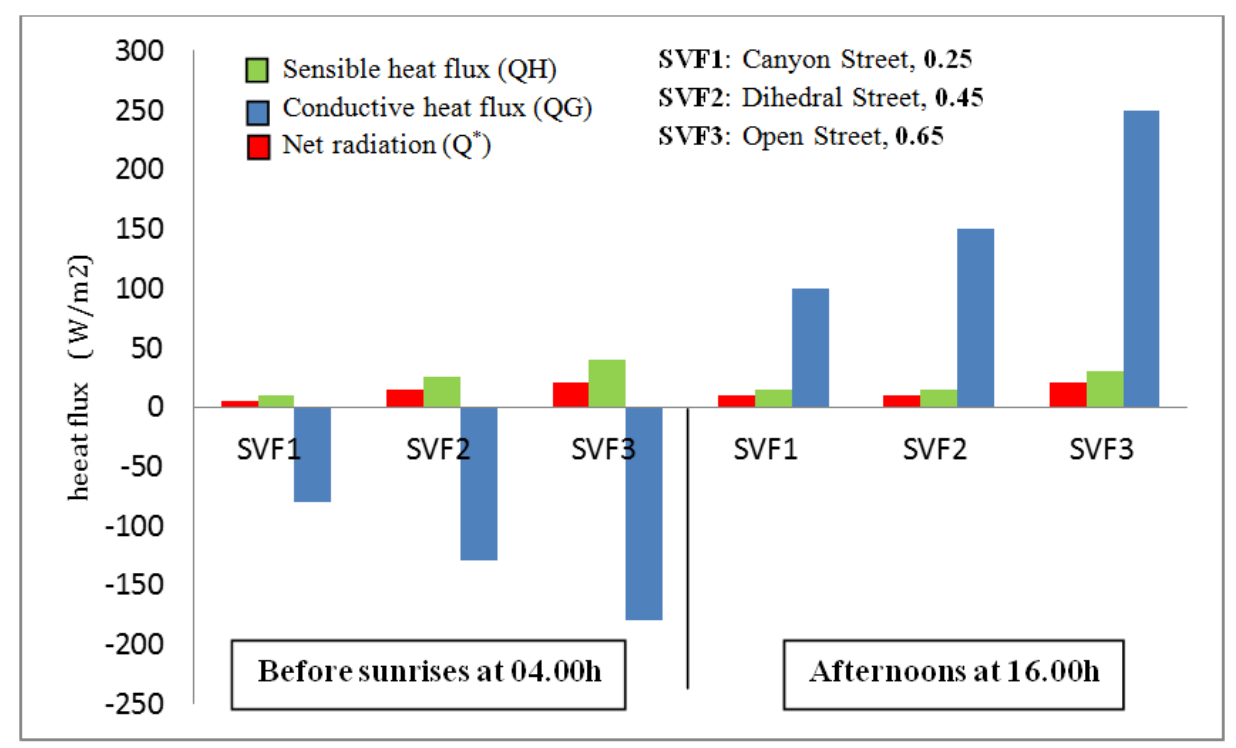

Fig. 8. Relationship between SVF and the sensible heat flux $(\mathrm{QH})$, conductive heat flux $(\mathrm{QG})$ and net radiation $\left(Q^{*}\right)$.

Before sunrise $(4.00 \mathrm{~h})$ and afternoons $(16.00 \mathrm{~h})$ : The figure 9 and table 5 show a relation between the Sky View Factor (SVF) and thermal storage, this means that if SVF increases (open space) the energy storage also increases, since the facade is exposed to the sun.

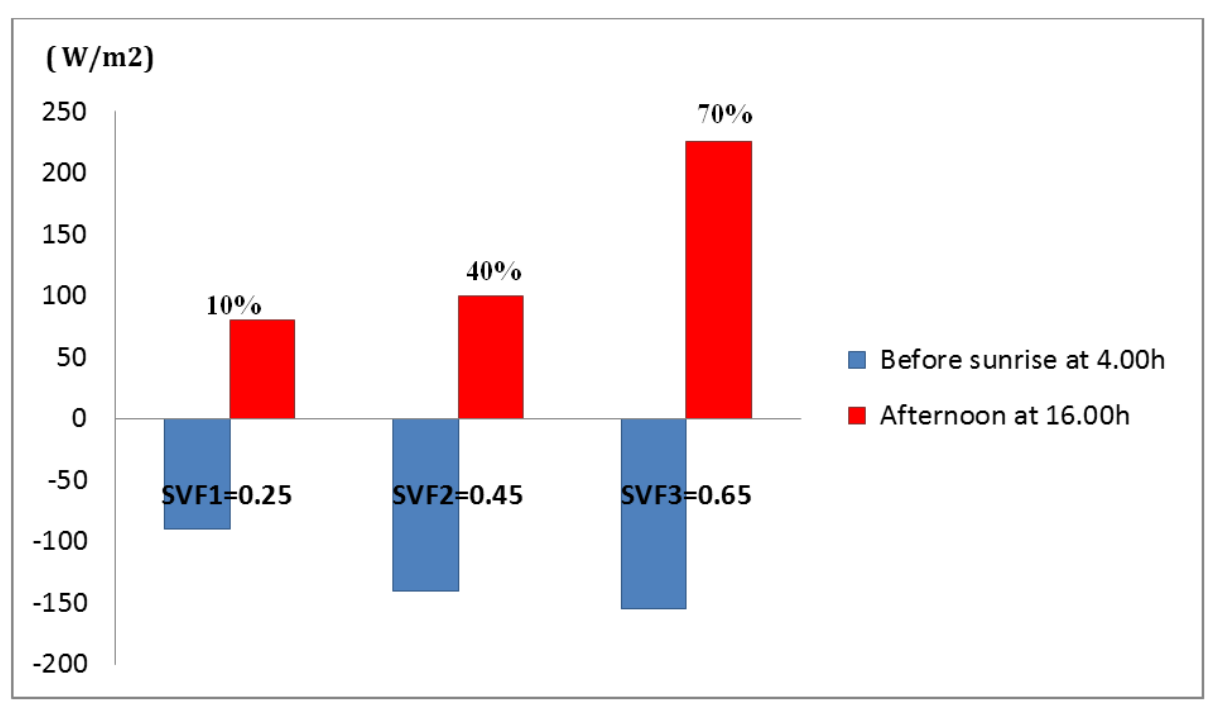

Fig. 9. Relationship between SVF and the thermal storage before sunrise and afternoon.

Table 5. Thermal storage in the afternoons and before sunrises in the three types of streets

\begin{tabular}{|c|c|c|c|}
\hline Street & SVF1 $=0.25$ & SVF2=0.45 & SVF3=0.65 \\
\hline Thermal storage before sunrises 04.00h $(\mathrm{w} / \mathrm{m} 2)$ & -90 & -140 & -155 \\
\hline Thermal storage in afternoons 16.00h $(\mathrm{w} / \mathrm{m} 2)$ & 80 & 100 & 225 \\
\hline Percentage of real thermal storage $(\mathrm{w} / \mathrm{m} 2)$ & $10 \%$ & $40 \%$ & $70 \%$ \\
\hline
\end{tabular}

\section{Conclusion}

The obtained results show that the (SVF) has a significant impact on thermal storage in buildings. The percentage of thermal storage in the case of Canyon Street (SVF $=0.25$ ) is $10 \%$, while in the case of Dihedral Street (SVF=0.45) it is $40 \%$. In the case of Open Street $(\mathrm{SVF}=0.75)$, the value is $70 \%$.

In order to improve the performance of urban energy and reduce the storage of heat in buildings and active air conditioning, it is necessary to act on morphological indicators of the streets. For 
hot and dry climate, the Sky View Factor for the streets (SVF) should be between 0.25 and 0.45 , which means that the urban fabric should be dense; this fabric shape seems to be the most appropriate morphology to reducing the heat storage, when varying in the SVF interval mentioned.

\section{References}

Adolphe, L. (2001). Modelling the link between built environment and urban climate: towards simplified indicators of the city environment, Building Simulation, Proceedings of IBPSA (International Building Performance Simulation Association), pp. 679-684.

Ahmed Ouameur, F. (2007). Urban morphology and thermal comfort in public spaces: Comparative study between three urban forms of the city of Quebec, thesis of the master, University of Laval, Quebec.

Arantes, L., Marry, S., Baverel, O., \& Quenard, D. (2016). Energy balance in the urban built environment: a" morpho-energetic" optimisation tool, CYBERGEO-EUROPEAN JOURNAL OF GEOGRAPHY.

Benamor, K. (2017). L'impact de la morphologie urbaine sur la demande énergétique dans les zones arides-Cas d'un tissu urbain éparse, cité 76 logements à Biskra. Magister dissertation, University Mohamed Khider-Biskra, Algeria.

Bouyer, J. (2009). Modeling and simulation of urban microclimates: Study of the impact of urban development on the energy consumption of buildings, Doctoral Thesis, University of Nantes, France.

Colombert, M . (2008). Contribution to the analysis of the taking into account of the urban climate in the various means of intervention on the city, Doctoral Thesis, University Paris-East.

Coquillaud , S. (2015). Climate change : Nature Reserves of France, (3 ${ }^{\text {rd }}$ Ed.), France: Impro, Montreuil.

Golany, G. S. (1996). Urban design morphology and thermal performance. Atmospheric Environment, 30(3), 455-465.

Masson, V., Grimmond, C. S. B., \& Oke, T. R. (2002). Evaluation of the Town Energy Balance (TEB) scheme with direct measurements from dry districts in two cities. Journal of applied meteorology, 41(10), 1011-1026.

Nikolopoulou, M., Baker, N., \& Steemers, K. (1999). Thermal comfort in urban spaces: different forms of adaptation. Proc. REBUILD 1999: Shaping Our Cities for the 21st Century.

Oke, T. R., \& Cleugh, H. A. (1987). Urban heat storage derived as energy balance residuals. Boundary-Layer Meteorology, 39(3), 233-245.

Parmentier, A . (2010). Development of a decision support tool to mitigate urban heat island phenomenon, thesis of the master, Superior Technology School, University of Quebec. 